"Assessing variations in foreign direct investments under international financial reporting standards (IFRS) adoption, macro-socioeconomic developments and credit ratings"

\begin{tabular}{ll} 
& Evangelos Daskalopoulos \\
AUTHORS & $\begin{array}{l}\text { Anastasios Evgenidis } \\
\text { Athanasios Tsagkanos } \\
\text { Costas Siriopoulos } \text { iD https://orcid.org/0000-0003-1368-7182 }\end{array}$ \\
& $\begin{array}{l}\text { Evangelos Daskalopoulos, Anastasios Evgenidis, Athanasios Tsagkanos and } \\
\text { Costas Siriopoulos (2016). Assessing variations in foreign direct investments } \\
\text { under international financial reporting standards (IFRS) adoption, macro- }\end{array}$ \\
ARTICLE INFO & $\begin{array}{l}\text { Socioeconomic developments and credit ratings. Investment Management and } \\
\text { Financial Innovations, 13(3-2), 328-340. doi:10.21511/imfi.13(3-2).2016.05 }\end{array}$ \\
\hline DOI & http://dx.doi.org/10.21511/imfi.13(3-2).2016.05 \\
\hline RELEASED ON & Monday, 10 October 2016 \\
\hline JOURNAL & "Investment Management and Financial Innovations" \\
\hline FOUNDER & LLC “Consulting Publishing Company "Business Perspectives"
\end{tabular}

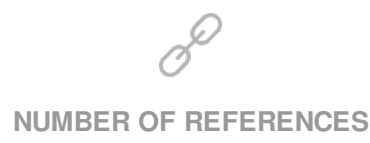

0
NUMBER OF FIGURES

0

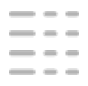

NUMBER OF TABLES

0

(C) The author(s) 2023. This publication is an open access article. 
Evangelos Daskalopoulos (Greece), Anastasios Evgenidis (Ireland), Athanasios Tsagkanos (Greece), Costas Siriopoulos (United Arab Emirates)

\title{
Assessing variations in foreign direct investments under international financial reporting standards (IFRS) adoption, macro-socioeconomic developments and credit ratings
}

\begin{abstract}
The main purpose of this paper is to investigate the impact of an endogenous relationship between international financial reporting standards (IFRS) and sovereign credit ratings on the factors that determine foreign direct investments, by using an instrumental variable panel data framework. The results show that the adoption of IFRS by developed economies is interpreted by credit rating agencies as a positive sign that the firms will provide more transparent financial reports. In addition, the authors find that the consideration of the endogenous relationship between IFRS and credit ratings for developed economies highlights the importance of some variables that was not evident previously such as the degree of corruption and the educational level. Finally, the authors suggest that foreign direct investments are more easily attracted when one considers a joint factor which captures people's perceptions about the ability of the government to implement policy and regulations that promote the development of public and private sector.
\end{abstract}

Keywords: credit ratings, IFRS, FDI determinants.

JEL Classification: C23, C26, M41, E51.

\section{Introduction}

IFRS have been adopted by more than 120 countries over the last ten years, while many other countries are moving in the same direction. This is evidence that a significant development in accounting laws is taking place internationally. Barth et al. (2008); Morais and Curto (2009) underscored that IFRS provides more comprehensive, valuable and comparable information rather than the local accounting standards. In addition, Armstrong et al. (2010) highlighted the necessity to adopt IFRS due to the fact that the quality of service is more sophisticated, while asymmetric information problems are reduced. The reduction in asymmetric information would, in turn, lead some firms into more transparency policies.

The increase in the transparency of financial reports as a result of international financial reporting standards (IFRS) adoption by a country has been shown to increase its foreign direct investments (FDI) mainly because of the reduction in the cost of data processing and data asymmetry (Humphrey et al., 2009; Shima and Gordon, 2011). However, a country's decision on the adoption of IFRS may be largely dependent on whether it believes that it would provide a strong signal to the credit rating agencies that the firms have improved their

\footnotetext{
(C) Evangelos Daskalopoulos, Anastasios Evgenidis, Athanasios Tsagkanos, Costas Siriopoulos, 2016.

Evangelos Daskalopoulos, Department of Business Administration, University of Patras, University Campus, Greece.

Anastasios Evgenidis, Central Bank of Ireland, Monetary Policy Division, Dublin, Ireland.

Athanasios Tsagkanos, Department of Business Administration, University of Patras, University Campus, Greece.

Costas Siriopoulos, Zayed University, College of Business, United Arab Emirates.
}

transparency and creditworthiness, thereby resulting in an increase of the country's sovereign credit rating. In light of the above, this paper, first, offers a recent evidence of the impact of IFRS in attracting FDI by incorporating also the effects of various socioeconomic and macroeconomic determinants. Second, it considers the endogenous relationship between sovereign credit ratings and IFRS adoption, for the first time, in the literature and it discusses how this relationship has altered the dynamics that move FDI in the world economies.

We highlight some important findings in our empirical framework which we think add novel value to the literature. First, the adoption of worldwide acceptable accounting standards by developed economies is beneficial in upgrading their sovereign credit ratings. Second, IFRS adoption continues to have an important effect on attracting foreign investments in both developed and developing economies even after taking into account the significance of unemployment rate in determining FDIs. Third, the consideration of the endogenous relationship between IFRS and credit ratings for developed economies highlights the importance of some variables that was not evident previously. For instance, the degree of corruption and the educational level have now a significant effect in FDIs. Finally, we find that foreign investments are easily attracted when we consider a joint factor that captures people's perceptions about the ability of the government to implement policy and regulations that promote the development of public and private sector.

The remainder of this paper is organized as follows. Section 1 provides the literature review, section 2 presents the econometric framework and the 
description of the data. Section 3 presents and discusses the results, while the last section concludes and provides policy implications.

\section{Literature review and theoretical background}

The adoption of IFRS has been found to be one of the most important factors in attracting higher levels of foreign investment. Marquez-Ramos (2008) and Chen et al. (2014) examine the IFRS adoption as a moving force of FDI, based on the gravity model of trade $^{1}$. They find that the adoption of IFRS enforces mutual trade in goods and direct investments between countries. Gordon et al. (2012) use a panel data approach to examine the effects of IFRS along with other macroeconomic and socioeconomic variables on total FDI inflows for a large set of countries. They witnessed evidence that the IRFS adoption leads to increased FDI inflows, especially in developing economies.

Compared to this literature, we extend the vector of explanatory variables by considering two more variables within the FDI-IFRS framework: one macroeconomic variable which is the unemployment rate and the other one is a socioeconomic variable, i.e., the educational level. High unemployment rates have been found positively affect FDI because of the low labor cost which attracts FDIs (Botrić and Škuflić, 2006). Similarly, Noorbakhsh et al. (2001) and Asiedu (2002) suggested that human capital has a significant positive impact on attracting foreign investments. The idea behind the use of these variables is twofold: to obtain a wider set of information of FDI determinants and to evaluate the ability of IFRS adoption to attract FDI over and above that contained in unemployment rate and educational level.

So far, none of the relative studies has taken into account the fact that the adoption of IFRS by a country may positively affect its sovereign credit rating. This paper addresses this puzzle from a different angle which, to our knowledge, innovates and contributes to filling some existing gaps in the literature. We consider a new perspective by deriving an instrumental variable (IV) panel-data framework that assumes the addition of the two macro-socio variables and takes into account the endogenous relationship between IFRS and credit ratings. The economic rationale behind this relationship is that a country is more likely to decide on the adoption of IFRS if it expects that this movement would be interpreted by credit rating agencies as a sign that the firms in that country will provide more transparent financial reports. Therefore, the positive signal might have a

\footnotetext{
${ }^{1}$ The gravity model is one of the main devices used to analyze the determinants of international trade flows.
}

beneficial effect on the country's ability to increase its sovereign rating and attract more FDIs.

According to the insights provided by the literature relative to the ability of a country to attract foreign direct investments and credit ratings, a sovereign credit rating change may affect foreign direct investments via two different paths: first, through credit rating's effect on the cost of capital. In particular, a flight-to-quality will push investors to move the capital away from high risk investments and search for the safest possible investment options (Hartmann et al., 2004; Pavlova and Rigobon, 2008). In addition, Reinhart and Rogoff (2004) suggested that capital flows from rich countries to poor countries are largely dependent on the sovereign countries' credit ratings. The second path through which sovereign credit rating changes may affect foreign direct investments is by risk premiums. It has been shown that capital flows affect the liquidity of financial markets and, hence, risk premiums. Accordingly, Levine and Zervos (1998) document that capital flows affect stock market liquidity, while Amihud et al. (1997) and Beber et al. (2009) document evidence that liquidity affects the equity premium, and bond premium correspondingly. A direct examination of the impact of sovereign rating changes on private investments has been conducted by Kim and Wu (2008). They find that different types of sovereign credit ratings may affect financial development and international capital flows such as international banking, portfolio flows and foreign direct investments. In addition, Chen et al. (2013) find that sovereign credit rating changes have an influence on real private investments of rerated countries.

Our paper has a number of distinct features. First, we add to the existing literature by highlighting the important role of sovereign credit ratings in altering the contribution of many FDI determinants. Second, this effect is accomplished by estimating in a two step procedure - IV-panel data framework that incorporates credit rating as an endogenous variable. Third, except for the usual macro-socio economic variables, we include in the FDI-IFRS analysis the effect of two extra components that have been found to largely affect FDI: the unemployment rate and the effect of education level. Fourth, the period of analysis runs from 1996 to 2014 to take into account the impact of 2007 major economic slowdown and the European sovereign debt crisis (2010). This allows us to reveal some important effects that might not have been captured by the previous studies which had neglected the latest major economic events. In addition, this study considers a large dataset consisted of 142 developed and developing economies including data from major Eurozone countries. Gordon et al. (2012) have also 
used a dataset of 124 countries, but they exclude all major Euro area countries from their sample, which may had significantly affected the results given their key role in the world economy.

\section{Methodology and data used}

2.1. Model set up. The effect of IFRS plus a number of other variables on the FDI is examined by the following panel data regression model:

$Y_{i t}=\left(a+u_{i}\right)+X_{i t}^{\prime} \beta+\varepsilon_{i t}$,

for $i=1, \ldots n$ countries and $t=1, \ldots T$ time periods. $X_{i}$ is a $k \times T_{n}$ matrix where $k$ is the number of independent variables, $\beta$ is a $k x_{1}$ matrix of coefficients, $Y_{i}$ is $n T \mathrm{x} 1$ and it contains FDI, while $\varepsilon_{i t} \sim \operatorname{IID}\left(0, \sigma_{\varepsilon}^{2}\right)$ is the error term of dimension $n T x_{1} ; u_{i}$ is a random variable that is part of the intercept $\alpha$ under the fixed effects model and it is assumed that it is uncorrelated with the vector of explanatory variables. The fixed group effect model examines group differences in intercepts, assuming the same slopes and constant variance across the countries. We consider this effect in our study since it allows us to capture unobserved heterogeneity across the countries where it is fixed over time.

However, the fixed effects does not take into account the fact that the variation across countries may be random and uncorrelated with FDI and the other independent variables included in equation (1). Therefore, we also estimate the random effects model as follows:

$$
Y_{i t}=a+X_{i t}^{\prime} \beta+\left(u_{i}+\varepsilon_{i t}\right) \text {. }
$$

The random effects model, in contrast with fixed effects, estimates variance components for countries (or times) and error, assuming the same intercepts and slopes. Notice that the random component $u_{i}$ is now a part of the errors. This implies that now the difference among the countries lies in their variance of the error term, not in their intercepts. The fixed effects model is estimated by using a least squares dummy variable (LSDV) estimator ${ }^{2}$, while the random effects model is estimated by the SwamyArora (1972) feasible GLS estimator (1972). We use two tests to decide between a fixed/random effects regression and a pooled OLS. Fixed effects are tested by the incremental F-test, while random effects are examined by the Lagrange Multiplier (LM) test (Breusch and Pagan, 1980). In both tests, rejection of the null hypothesis implies that the fixed effects or/and the random effects, respectively, are appropriate methods. Then, a third test proposed by

\footnotetext{
${ }^{2}$ The estimation of fixed effects model via dummy variables is easily implemented by adding a $n-1$ vector of dummies in equation (1) and estimating using pooled OLS.
}

Hausman (1978) is used to decide between fixed and random effects models. If the null hypothesis is not rejected, that is, the individual effects are uncorrelated with the other independent variables in the model, the random effects model is preferred.

2.2. Data description. The estimation period is running from 1996 to 2014 and the data frequency is annually. The full dataset which contains all developed and developing countries consists of 142 countries with 19 observations for each country. While we consider a large number of variables for a very large number of countries, not all variables are available for each country. We split the data between developing and developed economies. The distinction of the countries among these two categories is based on the World Bank and it can be seen in Table AP1. Overall, the number of countries that are characterized as developing are 111 , while the number of countries that are characterized as developed are 31 .

Following the relative literature (Bevan and Estrin, 2004; Ramasamy and Yeung, 2010), we use the following variables. The logarithmic transformation of FDI $(f d i)$ is used as a proxy of the inflow of FDIs. The macroeconomic variables used are the logarithmic transformation of GDP, GDP per capita (GDPcap), GDP growth rate per capita (GDPgr), exchange rates (exch), short term interest rate (rate) and a proxy for trade activity, which is the absolute value of exports plus imports as a percentage of real GDP (trade). The socio-economic variables used are the following. A mobile cellular subscription per hundred people is used as a proxy for infrastructure (infrast). We also use a variable which measures the citizens' freedom of expression (freedom). Higher values denote greater freedom of expression. The last variable measures the degree of corruption. A high value of this index denotes low levels of corruption, because higher values correspond to greater perceptions of the extent to which the public power is exercized for private gain.

The IFRS adoption (adifrs) is a dummy variable which equals to 1 if a country has adopted IFRS or 0 , otherwise. The last column of Table AP1 clearly reports which countries have adopted IFRS and which countries have not. The existing FDI framework is extended by adding two more measures, one from each category. Unemployment rate is used (unempl) as an additional macroeconomic factor. The relative literature has witnessed the effect of unemployment in foreign investments. Botrić and Škuflić (2006) have found a positive correlation between unemployment and FDI, which has attributed to the fact that the indicator is more suited to a measure of low cost labor which attracts foreign investments. Also, the 
secondary education level (educ) is used as a socioeconomic factor that captures the importance of education in attracting FDI. Noorbakhsh et al. (2001) and Asiedu (2002) showed that human capital has a significant positive impact on FDI, while the importance of the human capital for attracting foreign investment has increased over time.

Finally, to find the measure of sovereign credit rating, annual bond ratings published by Fitch, Moody's, and S\&P have been used. We follow previous research (Cantor and Packer, 1996) and convert the agency sovereign rating lettering system into ordinal values measured on a seventeen point 0 16 scale. The highest quality bond rating, which is an "AAA" grade, is denoted by 16 and the lowest quality rate, which is a "C" grade, is denoted by 0 . In case that a bond rating had changed in a given year, we use the rating that the country held for most months.

\section{Empirical results}

3.1. Recent evidence on the ability of IFRS to attract FDI. Discussion and implications. 3.1.1. Full sample. To verify whether the use of fixed or random effects is appropriate, we employ an incremental F-test and a Lagrange Multiplier test. Judging from the values of both tests (6.14 and 14.63 in $1 \%$ significance level) we reject the null of pooled OLS in favor of panel data estimation. The results from the fixed effects model are depicted in Table 1. The table represents the results from panel data regression models when the full sample is considered (142 countries). Fixed effects estimation is depicted in the second column, while random effects in the third column. Hausman test is also computed to compare fixed effect and random effect models.

Table 1. Panel data results - full sample

\begin{tabular}{|l|c|c|c|c|}
\hline \multirow{2}{*}{ Variable } & \multicolumn{2}{c|}{ Fixed effects } & \multicolumn{2}{c|}{ Random effects } \\
\hline adifrs & Coefficient & t-stat & Coefficient & t-stat \\
\hline GDP & 1.38 & 1.98 & 1.22 & 1.85 \\
\hline GDPcap & 0.33 & 3.04 & 0.39 & 4.25 \\
\hline GDPgr & 0.00 & 1.00 & 0.00 & 0.97 \\
\hline trade & -0.08 & -1.07 & -0.08 & -1.04 \\
\hline infrast & 0.01 & 0.84 & 0.00 & 0.74 \\
\hline exch & 0.00 & 0.60 & 0.01 & 0.82 \\
\hline rate & 0.00 & -0.15 & 0.00 & -0.32 \\
\hline freedom & -0.02 & -1.08 & -0.02 & -1.23 \\
\hline unempl & 1.24 & 1.04 & 0.25 & 0.30 \\
\hline educ & -0.34 & -3.57 & -0.24 & -3.21 \\
\hline corrupt & -0.01 & -0.70 & -0.01 & -0.56 \\
\hline $\mathrm{R}^{2}$ & 2.17 & 2.22 & 1.35 & 2.06 \\
\hline Adjusted R & \multicolumn{2}{|c|}{0.57} & \multicolumn{2}{c|}{0.55} \\
\hline F-stat & \multicolumn{2}{|c|}{0.50} & \multicolumn{2}{c|}{0.52} \\
\hline
\end{tabular}

\begin{tabular}{|l|c|c|}
\hline p-value & 0.00 & 0.00 \\
\hline Number of obs & 507 & 507 \\
\hline \multirow{2}{*}{ Hausman test } & $\mathrm{x}^{2}$-stat & $\mathrm{p}$-value \\
\cline { 2 - 3 } & 13.17 & 0.35 \\
\hline
\end{tabular}

Notes: The results are based on the panel regressions according to equations (1), second column and (2), third column. P-values are based on White robust standard errors. The significant coefficients are denoted in bold. The sample period is running from 1996 to 2014. The null hypothesis of Hausman test denotes that random effects are preferred from its fixed counterpart.

F-stat (8.33) is positive and significant, thus, we reject the null that none of the independent variables have predictive power on FDIs. In line with the relative literature (Chen et. al., 2014; Gordon et al., 2012), the coefficient of IFRS is positive and significant at $5 \%$ level. This is a clear indication that the adoption of IFRS positively affects FDI. Concerning the other variables of the model, GDP, which is the representative of the economic size of each country, is also found positive and significant. This is a reasonable finding, since it denotes that the largest economies attract more FDI. Another interesting finding is the negative significance of the coefficient of unemployment. This denotes that countries that exhibit high unemployment rates attract less foreign investments. Further, the positive sign of the corruption index verifies that countries which witness low levels of corruption attract more FDI.

In addition, the results indicate that the effect of many variables (such as exchange rates, the degree of participation in governance and freedom of expression and infrastructure elements) which found to be significant in the determination of FDI in other studies (Globerman and Shapiro, 2002; Gordon et al., 2012), now appear to lose their significance. There are two possible explanations for this phenomenon. First, the inclusion of a new variable which measures the proportion of the labor force which has a secondary education (educ), might affects the results. This is because when we run the regression model excluding this variable, we notice that exchange rates and infrast variables regain their significance ${ }^{3}$. This means that educ may lead to the maximization of standard errors of these two variables, thus, resulting in their insignificance. The second reason is that the extension of the sample size included the effect of post-2007 crisis period might had significantly altered the dynamics that move FDI.

\footnotetext{
3 The model without the variable educ has a smaller adjusted $\mathrm{R}^{2}$ compared with the initial model (0.44 versus 0.50$)$. In addition, AIC information criterion is much larger that of the initial model $(6.40$ versus 6.35). These results confirm the superiority of our initial chosen model with the inclusion of educ.
} 
We, next, turn our analysis to the random effects method. The results are depicted in the third column of Table 1. We apply this method so that to take into account possible differences across the countries that may have some influence on FDI. The results are almost similar to those from the fixed effects. IRFS, unemployment, GDP and corruption all remain the same in terms of sign and magnitude. The only variable that exhibits a pronounced difference between the two modes - in terms of magnitude - is freedom ( 0.24 from 1.24), but it still remains insignificant.

3.1.2. Splitting the sample between developed and developing economies. In this section, we present the results from splitting the data between developing and developed economies. Hausman test ( $x^{2}$ equals to 49.70 with $p$-value equals to 0.00 ) points out that the fixed effects model is more suitable in capturing the dynamics that move FDI for developed economies ${ }^{4}$. The second column of Table 2 shows the results under fixed effects.

Table 2 represents the results from panel data regression models when the sample is separated into developed and developing economies. The results for developed economies are depicted in the second column while the results for the developing economies are depicted in the third column. For each case, Hausman test is computed to choose between fixed and random effect models.

Table 2. Panel data results - developed and developing economies

\begin{tabular}{|c|c|c|c|c|}
\hline & \multirow{2}{*}{\multicolumn{2}{|c|}{ Developed economies }} & \multicolumn{2}{|c|}{ Developing economies } \\
\hline & (fixed effects) & & \multicolumn{2}{|c|}{ (random effects) } \\
\hline & Coefficient & t-stat. & Coefficient & t-stat \\
\hline \multicolumn{5}{|c|}{ Variable } \\
\hline adifrs & 1.23 & 1.66 & 2.13 & 1.88 \\
\hline GDP & 0.19 & 1.28 & 0.34 & 2.69 \\
\hline GDPcap & 0.00 & 1.45 & 0.00 & -0.72 \\
\hline GDPgr & -0.03 & -0.26 & -0.11 & -0.96 \\
\hline trade & 0.01 & 1.16 & 0.01 & 1.17 \\
\hline infrast & 0.00 & 0.44 & 0.01 & 0.69 \\
\hline exch & 0.01 & 0.80 & 0.00 & -0.64 \\
\hline rate & -0.01 & -0.82 & -0.02 & -0.85 \\
\hline freedom & 3.42 & 2.16 & 0.40 & 0.47 \\
\hline unempl & -0.45 & -4.43 & -0.25 & -2.56 \\
\hline educ & -0.02 & -1.06 & -0.01 & -0.54 \\
\hline corrupt & 1.78 & 1.51 & 1.09 & 0.91 \\
\hline $\mathrm{R}^{2}$ & \multicolumn{2}{|c|}{0.58} & \multicolumn{2}{|c|}{0.56} \\
\hline Adjusted R2 & \multicolumn{2}{|c|}{0.52} & \multicolumn{2}{|c|}{0.54} \\
\hline Number of obs. & \multicolumn{2}{|c|}{267} & \multicolumn{2}{|c|}{284} \\
\hline \multicolumn{5}{|l|}{ Hausman test } \\
\hline$x^{2}-$ stat. & \multicolumn{2}{|c|}{49.70} & \multicolumn{2}{|c|}{9.81} \\
\hline$p$-value & \multicolumn{2}{|c|}{0.00} & \multicolumn{2}{|c|}{0.63} \\
\hline
\end{tabular}

Notes: The results in column two are based on the fixed effects model as described by equation (1), while the results in the third column are based on the random effects model (2). P-values are based on White robust standard errors. The significant coefficients are denoted in bold. The sample period is running from 1996 to 2014. Hausman test indicated that fixed effects are preferred in the case of developed economies, while random effects are preferred for developing economies.

Judging from $t$-stats, unemployment, the degree of participation in governance and freedom of expression (freedom) play an important role in determining variations of FDI in developed countries. Equally important is the fact that the adoption of IRFS retains its strong and positive impact in FDI inflows in major countries. This is in contrast to Gordon et al. (2012), who find that IFRS adoption has no significant effect in FDI for developed economies. The reason for this is that the authors had not included in their dataset the impact of large Eurozone countries such as Germany, France, Italy and Spain. Given the significant interconnections between these countries and the rest of the world and the fact that all these countries have adopted international accounting standards, it is reasonable to assume that the omission of these effects could have affected the significance of the IFRS coefficient. Another interesting finding is related to the GDP coefficient. In contrast with the full model, this variable is now found insignificant. This finding is consistent with the relevant literature (Gordon et al., 2012) and it implies that the degree of economic growth between developed economies does not play any significant role in attracting FDI. An explanation for this is that these economies have a very strong capacity, strong educational systems, high levels of human capital, high levels of savings,

\footnotetext{
${ }^{4}$ The results from random effects (are not reported here for saving
} space) show no major differences compared with fixed effects. 
small fiscal constraints and more flexible mechanisms, so they are capable of attracting foreign investments independently of their economic size.

Last, we report the results from the panel regression in developing economies (see Table 2). Interestingly, Hausman test in contrast with the fixed effects, now favors the use of the random effects ( $x^{2}$ equals to 9.81 with a $\mathrm{p}$-value equals to $0.63)$. An implication behind this difference in model selection could be the following. Social, cultural, economic and political characteristics in each developing country influence the outcome of other independent variables, while differences across the developed economies have a more pronounced effect to FDI than in the explanatory variables. The third column of Table 1 shows the results from the random effects model. The first thing to notice is that the coefficient of IFRS remains positively significant. Therefore, the adoption of IFRS is of crucial importance in attracting foreign investors both in developed and developing countries. In contrast with the developed economies, the economic size of developing economies plays a major role in explaining the dynamics that affect FDI, thus, the significant coefficient of GDP found in the full model is mainly driven by its importance in emerging countries. The significant positive coefficient of GDP means that the developing economies should target in expanding their level of economic activity, since it is beneficial in attracting foreign investments.
3.2. Credit rating as a key drive of the system. The analysis so far has not taken into account the fact that a country's decision on the adoption of IFRS may be largely dependent on whether it believes that it would provide a strong signal to the credit rating agencies that the firms have improved their transparency and creditworthiness. This positive signal should result in an increase of the country's sovereign credit rating. Therefore, the endogenous relationship between IFRS and credit ratings might alter the dynamics that affect the country's ability to attract foreign direct investments.

We address this potential endogeneity by using an instrumental variable which captures each country's rating grade according to the three credit rating agencies (Moody's, S\&P, and Fitch Ratings). The model is estimated by using a two stage least squares (2SLS) method. The endogenous variable is adifrs; we use as instruments all the other independent variables plus the credit variable. Note that the first stage of the 2TLS method is a probit model, since the dependent variable is adifrs which is a binary variable.

The results are depicted in Table 3. On the left part of the table, we report the results from the developing economies. Table 3 represents the results from instrumental variables panel data estimation when the sample is separated into developed and developing economies. The results for developing economies are depicted in the left part of the table, while the results for the developed economies are depicted in the right part of the table.

Table 3. Instrumental variables estimation-credit variable

\begin{tabular}{|c|c|c|c|c|c|c|c|c|}
\hline & \multicolumn{4}{|c|}{ Developing economies } & \multicolumn{4}{|c|}{ Developed economies } \\
\hline & \multicolumn{2}{|c|}{ First stage } & \multicolumn{2}{|c|}{ Second stage } & \multicolumn{2}{|c|}{ First stage } & \multicolumn{2}{|c|}{ Second stage } \\
\hline & Coefficient & z-stat. & coefficient & t-stat. & Coefficient & z-stat. & Coefficient & t-stat. \\
\hline \multicolumn{9}{|l|}{ Variable } \\
\hline & & & & & & & & \\
\hline Credit & 0.01 & 0.16 & - & - & -0.12 & -2.08 & - & - \\
\hline Adifrs & - & - & 0.86 & 1.79 & - & - & 0.95 & 5.96 \\
\hline GDP & -0.10 & -2.11 & 0.38 & 1.43 & -0.04 & -1.26 & 0.03 & 0.37 \\
\hline GDPcap & 0.00 & 0.12 & 0.00 & -1.26 & 0.00 & 1.29 & 0.00 & -0.31 \\
\hline GDPgr & -0.02 & -1.03 & -0.03 & -0.20 & -0.11 & -3.15 & 0.13 & 2.66 \\
\hline Trade & 0.00 & -0.62 & 0.01 & 0.92 & 0.00 & 1.48 & 0.00 & -0.21 \\
\hline Infrast & 0.02 & 1.44 & -0.03 & -1.04 & 0.01 & 1.24 & 0.00 & 1.98 \\
\hline Exch & -0.01 & -1.85 & 0.02 & 0.92 & -0.01 & -2.72 & 0.00 & -0.01 \\
\hline Rate & -0.04 & -1.49 & -0.03 & -0.23 & -0.06 & -1.05 & 0.00 & -0.37 \\
\hline Freedom & 0.66 & 1.58 & -0.18 & -0.10 & 0.09 & 0.32 & 0.18 & 0.41 \\
\hline Unempl & 0.10 & 2.82 & -0.45 & -2.28 & -0.05 & -1.99 & -0.14 & -2.31 \\
\hline Educ & 0.02 & 2.22 & 0.06 & 1.16 & -0.01 & -1.31 & -0.01 & -2.21 \\
\hline Corrupt & -0.97 & -2.85 & 1.61 & 0.70 & -0.15 & -0.86 & 0.56 & 2.15 \\
\hline Dependent variable & \multicolumn{2}{|c|}{ adifs } & \multicolumn{2}{|c|}{$f d i$} & \multicolumn{2}{|c|}{ adifs } & \multicolumn{2}{|c|}{$f d i$} \\
\hline
\end{tabular}

Notes: The model is estimated by using a two stage least squares (2SLS) method. The endogenous variable is adifs. We use as instruments all the other independent variables plus the credit variable that captures sovereign credit rating based on a $0-16$ scale. The first stage of the 2TLS method is a probit model since the dependent variable is adifrs which is a binary variable. The second stage of 2TLS is the usual regression model which now contains the fitted values of adifrs from stage one. P-values are based on White robust standard errors. The significant coefficients are denoted in bold. 
The first stage of the 2TLS method shows that the coefficient of credit rating is insignificant. This means that an increase in the sovereign rating in emerging economies will not affect their decision about adopting IFRS. The results from the second stage do not change compared with these from the previous section. In particular, it is observed that that when we control for the endogenous relationship between the IFRS and sovereign ratings, there is an almost zero change in the significance of the coefficients compared with Table 2. Except for the economic size which is now slightly insignificant, employment and adoption are still significant, while all the other variables remain insignificant.

On the contrary, as the right part of Table 3 shows, the behaviour of developed economies is completely different. The coefficient of credit rating is now significantly negative. This result implies that the adoption of worldwide acceptable accounting standards by developed economies is beneficial in upgrading their sovereign credit ratings. Further, the inclusion of credit rating variable highlights the importance of some variables that have not been revealed previously. In contrast with the results from the LSDV model in Table 2, the coefficients of corruption and the educational level of labor force (educ) have a significant effect in FDI. The positive coefficient of corruption witnesses that the developed economies that manage to fight against corruption attract foreign investors. The negative coefficient of educ points out an equal interesting finding. Accordingly, the developed economies that have a high percentage of secondary education attract less FDI. This means that countries that experience a lower level of competitiveness due to lower wages for the unskilled attract more foreign direct investments.
3.3. Robustness checks. 3.3.1. Alternative explanatory variables. Following other similar studies (Marquez-Ramos, 2008; Gordon et al., 2012), we check the robustness of our results by including alternative explanatory variables into the panel regression models (1) and (2). As a first experiment, we use lawful as an alternative variable which indicates the agents' confidence in the rules of society, such as property rights, the police, the courts, and the likelihood of crime and violence. Higher values correspond to higher confidence by the public (see Table 1). The correlation between corruption and lawful for developing (developed) economies is very high, $0.85(0.91)$. For this reason, we exclude corruption from our models. Second, instead of lawful, we use another variable which is highly correlated with corruption, called govconf. This variable reflects the agents' perceptions about the ability of the government to formulate and implement policies that promote a private sector.

The results from both models for developed and emerging economies are depicted in the first two columns of Table 4 and Table 5, respectively.

Table 4 represents the results for developed economies, after considering alternative explanatory variables into the panel regression models. The first two columns contain two variables that measure different aspects of agents' perceptions about the rules of society and government policy. These variables are used instead of corruption. The last column contains the results from re-estimating the model by performing a principal component analysis (PCA) in the subset of highly-correlated variables; these are lawful, govconf and PCA component.

Table 4. Robustness checks-developed economies

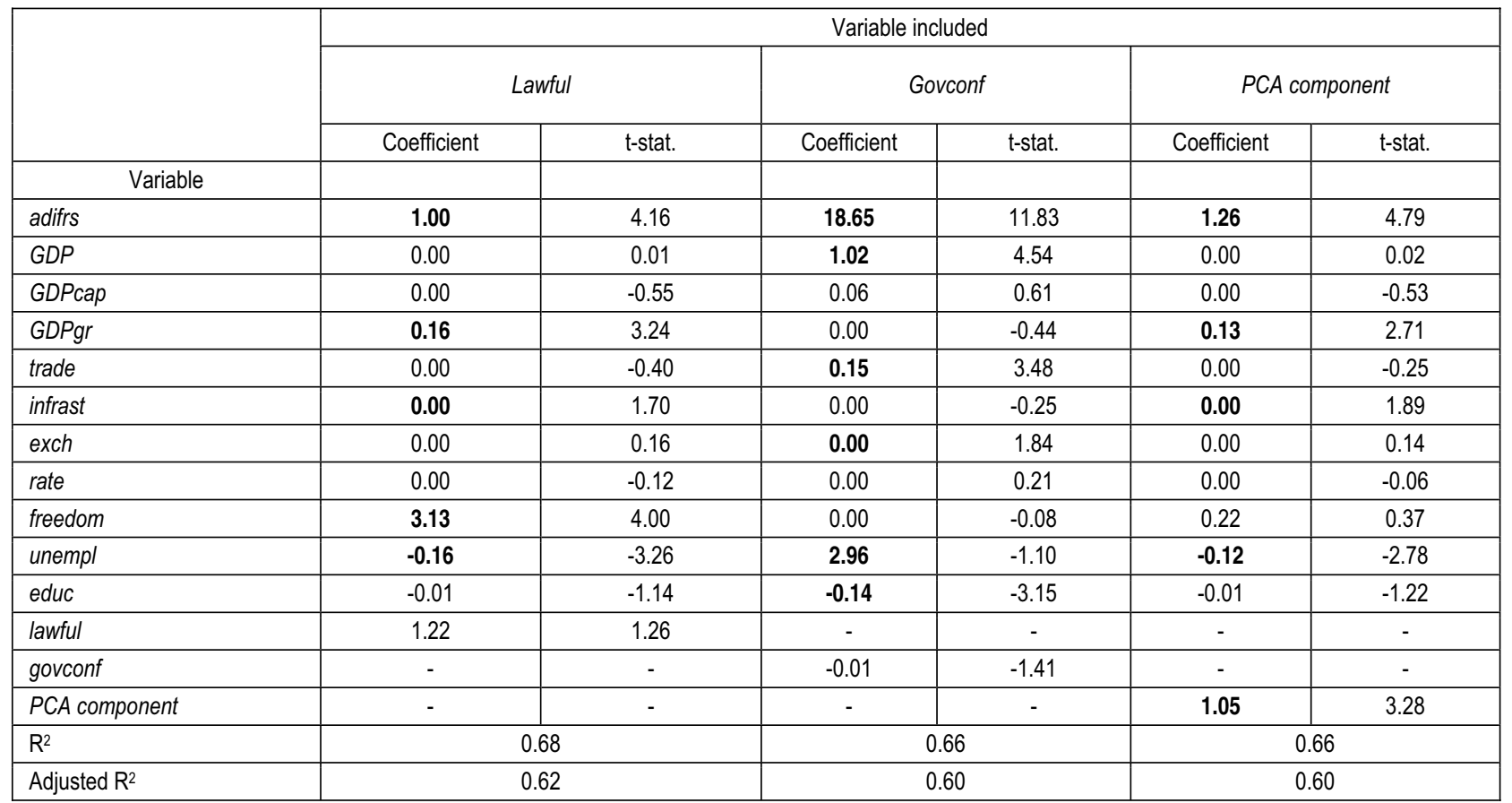


Table 5 represents the results for developing economies, after considering alternative explanatory variables into the panel regression models. The first two columns contain two variables that measure different aspects of the agents' perceptions about the rules of society and govern- ment policy. These variables are used instead of corruption. The last column contains the results from re-estimating the model by performing a principal component analysis (PCA) in the subset of highly-correlated variables; these are lawful, govconf and PCA component.

Table 5. Robustness checks-developing economies

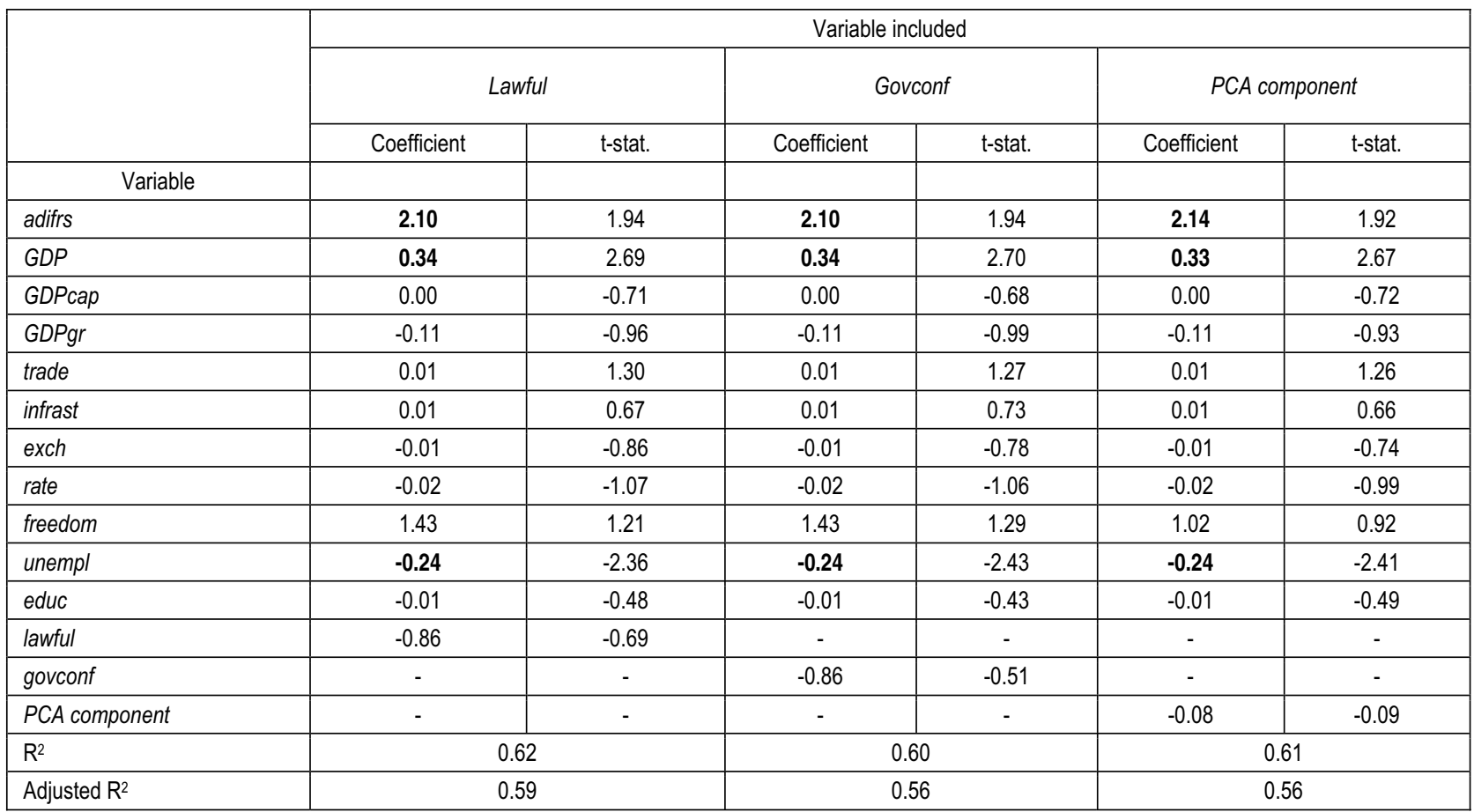

For developed economies, the results show no change in terms of their signs and only minor changes in terms of their significance and magnitude. When either lawful or govconf are used as explanatory variables, the impact of IFRS, freedom of expression and the unemployment rate continue to explain the dynamics that move direct investments. However, the significant impact of GDPgr and the infrastructure elements as denoted by infrast, have now come to the surface. For the emerging markets, the results show no difference in terms of sign, magnitude and significance.

3.3.2. PCA analysis. Corruption, lawful and govconf are three variables that measure different aspects of agents' perceptions about the rules of society and government policy. By including only one of these

Developing economies

Orthonormal Loadings

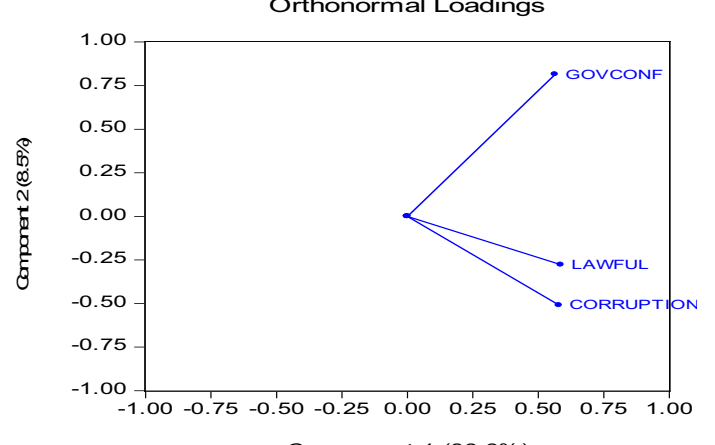

variables in the regressions we may lose information about how people form perceptions about the ability of the government to implement policy and regulations that promote the development of the public and private sector. Therefore, we reestimate our models by performing a principal component analysis (PCA) in this subset of highly-correlated variables. Thus, we achieve in reducing the dimensionality of the data and deal with the issue of multicollinearity.

The results from the PCA are depicted in Figure 1. It depicts the loading plots from a principal component analysis for developed and developing economies. The first component is considered in the horizontal axis and the second component is considered in the vertical axis.

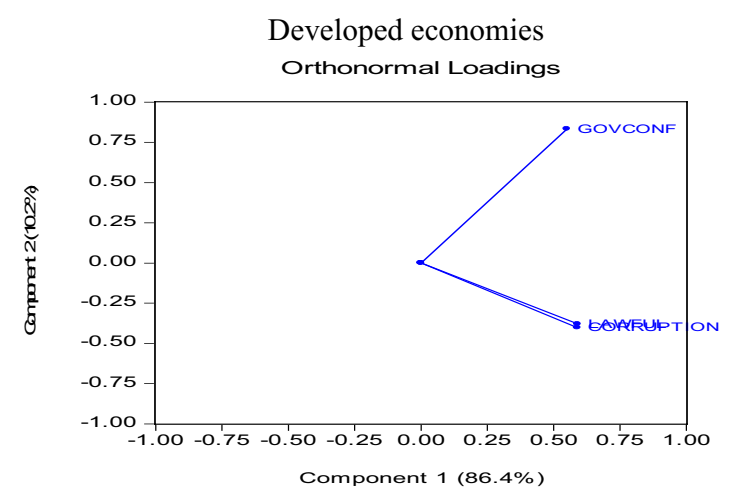

Fig. 1. PCA analysis 
Lines that go in the same direction and are close to one another indicate how the variables may be grouped. In this diagram, the first component in the horizontal direction is a summary of lawful and corruption. These variables are strongly correlated from a statistical point of view. The second component is closely related to govconf. The first principal component explains a very large portion of the variance of the three initial series $(86 \%)$ in both developed and emerging markets. This is a very good estimate, thus, we fit the first principal component in equations (1) and (2).

The third column of Tables 4 and 5 shows the results from the estimated models. As before, the results for developing countries are not sensitive to the use of PCA analysis. For developed economies, the results highlight the importance of GDP components and the infrastructure elements. This was exactly the case when either lawful or govconf are considered as explanatory variables. This implies that the PCA factor is more driven by these two variables than corruption. Equally important is the fact that while corruption was found insignificant in the initial models (see Table 2), the PCA coefficient is now positive and significant. Its significance brings into light one more important determinant of FDI. Accordingly, foreign investments are easily attracted when there are perceptions that agents in developed economies have confidence in and abide by the rules of society.

\section{Conclusions and implications}

The main goal of this paper is to describe the endogenous relationship between sovereign credit ratings and IFRS adoption, discusses how this relationship might have altered the dynamics that move FDI in world economies and derives the implications based on these hypotheses. We report a number of significant results that, from our point of view, add novel value to the literature.

First, the adoption of IRFS retains its strong and positive impact in FDI inflows in both developed and developing economies. From a policymaking perspective, this means that countries which have not adopted IFRS yet should move towards this direction. In addition, these countries could offer some sort of incentives to encourage the appropriate accounting standard setters to adopt IFRS (for instance, a tax incentive to business would help the firms subsidize the cost associated with implementing IFRS). Second, another important lesson to be learned from our analysis is that the adoption of IFRS especially by developed economies is beneficial in upgrading their sovereign credit ratings. This finding implies that this effect is more pronounced for countries that had stronger legal enforcement and investor protection before the transition. Third, unemployment significantly affects FDI, while IFRS adoption continues to have an important effect on attracting foreign investments, even after taking into account the effect of unemployment rate. From a policymaking point of view, this implies that countries should keep fight against unemployment and drive at the development of their institutional capacity as they pursue the IFRS adoption. By institutional development, we mean policies and regulations that will promote private investment, rule of law, property right and protection, the police, the courts and the control of corruption. When these structures are in place, then, countries can rely on these settings to attract IFRS. Fourth, the endogenous relationship between IFRS and credit ratings for developed economies highlights the importance of some variables in determining FDI, which was not evident previously; these are the degree of corruption and the educational level. Regarding the former, it implies that developed economies that manage to fight against corruption attract foreign investors. Regarding the latter, the negative coefficient points out that those economies which experience a low percentage of secondary education attract more FDI. Last, the results indicate that FDI are easily attracted when agents in the developed economies have confidence in and abide by the rules of society.

The impact of 2007 financial crisis might gave rise to structural breaks in the regression coefficients and, therefore, the relationship that describes the effect of IFRS adoption, macroeconomic, and socioeconomic variables on FDI might be nonlinear. For this reason, we believe that an important line of future research is to consider this relationship within a Markov-switching panel data model which would allow identifying two different regimes, one that represents economic expansion and another that represents economic contraction.

\section{References}

1. Amihud, Y., Mendelson, H. and Lauterbach, B. (1997). Market Microstructure and Securities Values: Evidence from the Tel Aviv Stock Exchange, Journal of Financial Economics, 45, pp. 365-390.

2. Armstrong, C.S., Barth, M.E., Jagolinzer, A.D., Riedl, E.J. (2010). Market reaction to the adoption of IFRS in Europe, The Accounting Review, 85(1), pp. 31-61.

3. Asiedu, E. (2002). On the Determinants of Foreign Direct Investment to Developing Countries: Is Africa Different? World Department, 30 (1), pp. 107-119.

4. Barth, M.E., Landsman, W.R., Lang, M.H. (2008). International accounting standards and accounting quality, Journal of Accounting Research, 46 (5), pp. 467-498. 
5. Beber, A., Brandt, M.W. and Kavajecz, K.A. (2009). Flight-to-Quality or Flight-to-Liquidity? Evidence from the Euro-Area Bond Market, Review of Financial Studies, 22, pp. 925-957.

6. Bevan, A.A. and Estrin, S. (2004). The Determinants of Foreign Direct Investment Into European Transition Economies, Journal of Comparative Economics, 32 (4), pp. 775-787.

7. Botrić, V., Škuflić, L. (2006). Main Determinants of Foreign Direct Investment in the Southeast European Countries, Transition Studies Review, 13, pp. 359-377.

8. Breusch, T.S. and Pagan, A.R. (1980). The Lagrange Multiplier Test and Its Applications to Model Specification in Econometrics, Review of Economic Studies, 47 (1), pp. 239-253.

9. Cantor, R. and Packer, F. (1996). Determinants and Impact of Sovereign Credit Ratings, Economic Policy Review, 2 (2), pp. 37-53.

10. Chen, C.J.P., Ding, Y. \& Xu, B. (2014). Convergence of Accounting Standards and Foreign Direct Investment, The International Journal of Accounting, 49(1), pp. 53-86.

11. Chen, S.S., Chen, H.Y., Chang, C.C. and Yang, S.L. (2013). How Do Sovereign Credit Rating Changes Affect Private Investment? Journal of Banking and Finance, 37 (12), pp. 4820-4483.

12. Globerman, S., Shapiro, D. (2002). Global Foreign Direct Investment Flows: The Role of Governance Infrastructure, World Development, 30 (11), pp. 1899-1919.

13. Gordon L., Loeb, M., Zhu, W. (2012). The Impact of IFRS Adoption on Foreign Direct Investment, Journal of accounting and public policy, 31, pp. 374-398.

14. Hartmann, P., Straetmans, S.T.M., de Vries, C.G. (2004). Asset Market Linkages in Crisis Periods, Review of Economics and Statistics, 86, pp. 313-326.

15. Hausman, J.A. (1978). Specification Tests in Econometrics, Econometrica, 46 (6), pp. 1251-1271.

16. Humphrey, C., Loft, A., Woods, M. (2009). The Global Audit Profession and the International Financial Architecture: Understanding Regulatory Relationships at a Time of Financial Crisis, Accounting and Society, 34 (6-7), pp. 810-825.

17. Kaufmann, D., Kraay, A. and Mastruzzi, M. (2009). Governance Matters VIII: Aggregate and Individual Governance Indicators 1996-2008, World Bank Policy, Research Working Paper Series 4978.

18. Kim, S.-J. and E. Wu. (2008). Sovereign Credit Ratings, Capital Flows and Financial Sector Development in Emerging Markets, Emerging Markets Review, 9 (1), pp.17-39.

19. Levine, R. and Zervos, S. (1998). Capital Control Liberalization and Stock Market Development. World Development, 26, pp. 1169-1183.

20. Marquez-Ramos, L. (2008). The Effect of IFRS Adoption on Trade and Foreign Direct Investments. Working paper, University Jaume I.

21. Márquez-Ramos, L. (2011). European Accounting Harmonization: Consequences of IFRS Adoption on Trade in Goods and Foreign Direct Investments, Emerging Markets Finance and Trade, 47, pp. 42-57.

22. Morais, J., Curto, D. (2009). Mandatory adoption of IASB standards: value relevance and country-specific factors, Australian Accounting Review, 49 (19), pp. 128-143.

23. Noorbakhsh, F., Paloni, A. and Youssef, A. (2001). Human Capital and FDI Flows to Developing Countries: A New Empirical Evidence, World Development, 29 (9), pp. 1593-1610.

24. Pavlova, A. and Rigobon, R. (2008). The Role of Portfolio Constraints in the International Propagation of Shocks, Review of Economic Studies, 75, pp. 1215-1256.

25. Ramasamy, B. and Yeung, M.C. (2010). The Determinants of Foreign Direct Investment in Services, World Economy, 33 (4), pp. 573-596.

26. Reinhart, C.M., Rogoff, K.S. (2011b). The Forgotten History of Domestic Debt, Economic Journal, 121, pp. 319-350.

27. Shima, K.M., Gordon, E.A. (2011). IFRS and the Regulatory Environment: The Case of U.S. Investor Allocation Choice, Journal of Accounting and Public Policy, 30 (5), pp. 481-500.

28. Swamy P.A.V.B. and Arora, S.S. (1972). The Exact Finite Sample Properties of the Estimators of Coefficients in the Error Components Regression Models, Econometrica, 40, pp. 261-275.

\section{Appendix}

Table AP1.

This table follows the World Bank in classifying each country in the sample, based on its level of development. The last column shows if the country has adopted IFRS or not.

\begin{tabular}{|l|l|c|c|}
\hline \multicolumn{1}{|c|}{ Country } & Developing & Developed \\
\hline 1 & Albania & $\mathrm{x}$ & $\mathrm{x}$ \\
\hline 2 & Algeria & $\mathrm{x}$ & \\
\hline 3 & Antigua and Barbuda & $\mathrm{x}$ & $\mathrm{x}$ \\
\hline 4 & Argentina & $\mathrm{x}$ & $\mathrm{x}$ \\
\hline 5 & Armenia & $\mathrm{x}$ & \\
\hline 6 & Australia & $\mathrm{x}$ & $\mathrm{x}$ \\
\hline 7 & Austria & $\mathrm{x}$ & $\mathrm{x}$ \\
\hline
\end{tabular}


Table AP1 (cont.).

\begin{tabular}{|c|c|c|c|c|}
\hline & Country & Developing & Developed & IFRS adoption \\
\hline 8 & Azerbaijan & $\mathrm{x}$ & & $\mathrm{x}$ \\
\hline 9 & Bahamas & & $x$ & $x$ \\
\hline 10 & Bahrain & $x$ & & $x$ \\
\hline 11 & Barbados & $x$ & & $x$ \\
\hline 12 & Belarus & $x$ & & $x$ \\
\hline 13 & Benin & $x$ & & \\
\hline 14 & Bhutan & $x$ & & \\
\hline 15 & Bolivia & $x$ & & $x$ \\
\hline 16 & Brazil & $x$ & & $x$ \\
\hline 17 & Brunei Darussalam & & $x$ & $x$ \\
\hline 18 & Bulgaria & & $x$ & $x$ \\
\hline 19 & Burkina Faso & $x$ & & \\
\hline 20 & Burundi & $x$ & & \\
\hline 21 & Cambodia & $x$ & & $x$ \\
\hline 22 & Cameroon & $x$ & & \\
\hline 23 & Canada & & $x$ & $x$ \\
\hline 24 & Chile & $x$ & & $x$ \\
\hline 25 & China & $x$ & & $x$ \\
\hline 26 & Colombia & $x$ & & $x$ \\
\hline 27 & Costa Rica & $x$ & & $x$ \\
\hline 28 & Côte D'ivoire & $x$ & & \\
\hline 29 & Croatia & $x$ & & $x$ \\
\hline 30 & Cyprus & & $x$ & $x$ \\
\hline 31 & Czech Republic & $x$ & & $x$ \\
\hline 32 & Denmark & & $x$ & $x$ \\
\hline 33 & Ecuador & $x$ & & $x$ \\
\hline 34 & Egypt, Arab Republic & $x$ & & \\
\hline 35 & El Salvador & $x$ & & $x$ \\
\hline 36 & Estonia & $x$ & & $x$ \\
\hline 37 & Fiji & $x$ & & $x$ \\
\hline 38 & Finland & & $x$ & $x$ \\
\hline 39 & France & & $x$ & $x$ \\
\hline 40 & Gambia & $x$ & & $x$ \\
\hline 41 & Georgia & $x$ & & $x$ \\
\hline 42 & Germany & & $x$ & $x$ \\
\hline 43 & Ghana & $x$ & & $x$ \\
\hline 44 & Greece & & $x$ & $x$ \\
\hline 45 & Grenada & $x$ & & $x$ \\
\hline 46 & Guatemala & $x$ & & $x$ \\
\hline 47 & Guyana & $x$ & & $x$ \\
\hline 48 & Haiti & $x$ & & $x$ \\
\hline 49 & Honduras & $x$ & & $x$ \\
\hline 50 & Hungary & $x$ & & $x$ \\
\hline 51 & Iceland & & $x$ & $x$ \\
\hline 52 & India & $x$ & & \\
\hline 53 & Indonesia & $x$ & & \\
\hline 54 & Iran, Islamic Republic & $x$ & & \\
\hline 55 & Ireland & & $x$ & $x$ \\
\hline 56 & Israel & & $x$ & $x$ \\
\hline 57 & Italy & & $x$ & $x$ \\
\hline 58 & Jamaica & $x$ & & $x$ \\
\hline 59 & Japan & & $x$ & $x$ \\
\hline 60 & Jordan & $x$ & & $x$ \\
\hline 61 & Kenya & $x$ & & $x$ \\
\hline 62 & Korea, Republic & $x$ & & $x$ \\
\hline 63 & Kuwait & & $x$ & $x$ \\
\hline
\end{tabular}


Table AP1 (cont.).

\begin{tabular}{|c|c|c|c|c|}
\hline & Country & Developing & Developed & IFRS adoption \\
\hline 64 & Kyrgyz Republic & $\mathrm{x}$ & & $x$ \\
\hline 65 & Lao Pdr & $x$ & & $x$ \\
\hline 66 & Latvia & $x$ & & $x$ \\
\hline 67 & Lebanon & $\mathrm{x}$ & & $\mathrm{x}$ \\
\hline 68 & Lesotho & $x$ & & $x$ \\
\hline 69 & Liberia & $x$ & & $x$ \\
\hline 70 & Lithuania & $\mathrm{x}$ & & $\mathrm{x}$ \\
\hline 71 & Luxembourg & & $\mathrm{x}$ & $x$ \\
\hline 72 & Macao Sar, China & & $x$ & $x$ \\
\hline 73 & Macedonia, Fyr & $x$ & & $\mathrm{x}$ \\
\hline 74 & Madagascar & $x$ & & $x$ \\
\hline 75 & Malawi & $x$ & & $x$ \\
\hline 76 & Malaysia & $x$ & & . \\
\hline 77 & Mali & $x$ & & \\
\hline 78 & Malta & $x$ & & $x$ \\
\hline 79 & Mauritius & $x$ & & $x$ \\
\hline 80 & Mexico & $x$ & & $x$ \\
\hline 81 & Moldova & $x$ & & $x$ \\
\hline 82 & Mongolia & $x$ & & $x$ \\
\hline 83 & Morocco & $x$ & & $x$ \\
\hline 84 & Mozambique & $\mathrm{x}$ & & $x$ \\
\hline 85 & Namibia & $x$ & & $x$ \\
\hline 86 & Nepal & $x$ & & $x$ \\
\hline 87 & Netherlands & & $x$ & $x$ \\
\hline 88 & New Zealand & . & $x$ & $x$ \\
\hline 89 & Nicaragua & $x$ & & $x$ \\
\hline 90 & Nigeria & $x$ & & $x$ \\
\hline 91 & Norway & & $x$ & $x$ \\
\hline 92 & Oman & $x$ & & $x$ \\
\hline 93 & Pakistan & $x$ & & $x$ \\
\hline 94 & Panama & $x$ & & $x$ \\
\hline 95 & Papua New Guinea & $x$ & & $x$ \\
\hline 96 & Paraguay & $x$ & & $x$ \\
\hline 97 & Peru & $x$ & & $x$ \\
\hline 98 & Philippines & $x$ & & \\
\hline 99 & Poland & $x$ & & $x$ \\
\hline 100 & Portugal & & $x$ & $x$ \\
\hline 101 & Romania & $\mathrm{x}$ & & $\mathrm{x}$ \\
\hline 102 & Russian Federation & $x$ & & $x$ \\
\hline 103 & Samoa & $x$ & & $x$ \\
\hline 104 & Senegal & $\mathrm{x}$ & & \\
\hline 105 & Serbia & $x$ & & $x$ \\
\hline 106 & Seychelles & $x$ & & $x$ \\
\hline 107 & Sierra Leone & $\mathrm{x}$ & & $x$ \\
\hline 108 & Singapore & & $x$ & $x$ \\
\hline 109 & Slovak Republic & $x$ & & $x$ \\
\hline 110 & Slovenia & $x$ & & $\mathrm{x}$ \\
\hline 111 & South Africa & $x$ & & $x$ \\
\hline 112 & Spain & & $x$ & $x$ \\
\hline 113 & Sri Lanka & $x$ & & $x$ \\
\hline 114 & St. Kitts and Levis & $\mathrm{x}$ & & $x$ \\
\hline 115 & St. Lucia & $\mathrm{x}$ & & $x$ \\
\hline 116 & St. Vincent and the Grenadines & $x$ & & $x$ \\
\hline 117 & Suriname & $\mathrm{x}$ & & $x$ \\
\hline 118 & Swaziland & $x$ & & $x$ \\
\hline 119 & Sweden & & $\mathrm{x}$ & $x$ \\
\hline
\end{tabular}


Investment Management and Financial Innovations, Volume 13, Issue 3, 2016

Table AP1 (cont.).

\begin{tabular}{|c|c|c|c|c|}
\hline & Country & Developing & Developed & IFRS adoption \\
\hline 120 & Switzerland & & $x$ & $x$ \\
\hline 121 & Syrian Arab Republic & $x$ & & \\
\hline 122 & Tajikistan & $x$ & & $x$ \\
\hline 123 & Tanzania & $x$ & & $x$ \\
\hline 124 & Thailand & $x$ & & \\
\hline 125 & Togo & $x$ & & \\
\hline 126 & Tonga & $x$ & & $x$ \\
\hline 127 & Trinidad and Tobago & $x$ & & $x$ \\
\hline 128 & Tunisia & $x$ & & \\
\hline 129 & Turkey & $x$ & & $x$ \\
\hline 130 & Uganda & $x$ & & $x$ \\
\hline 131 & Ukraine & $x$ & & $x$ \\
\hline 132 & United Arab Emirates & $x$ & & $x$ \\
\hline 133 & United Kingdom & & $x$ & $x$ \\
\hline 134 & United States & & $x$ & \\
\hline 135 & Uruguay & $x$ & & $x$ \\
\hline 136 & Uzbekistan & $x$ & & \\
\hline 137 & Vanuatu & $x$ & & $x$ \\
\hline 138 & Venezuela, $\mathrm{Rb}$ & $x$ & & $x$ \\
\hline 139 & Vietnam & $x$ & & \\
\hline 140 & Yemen, Republic & $x$ & & $x$ \\
\hline 141 & Zambia & $x$ & & $x$ \\
\hline 142 & Zimbabwe & $\mathrm{x}$ & & $\mathrm{x}$ \\
\hline Total & & 112 & 30 & 120 \\
\hline
\end{tabular}

